\title{
Effect of the addition of sodium caseinate on the viability of cryopreserved buffalo semen
}

\section{Efeito da adição de caseinato de sódio sobre a viabilidade do sêmen bubalino criopreservado}

\author{
Fernando Evaristo da Silva ${ }^{1}$; Jaqueline Candido Carvalho ${ }^{2}$; Camila de Paula Freitas \\ Dell'Aqua ${ }^{3}$; Frederico Ozanam Papa ${ }^{4}$; Marc Roger Jean Marie Henry \\ Eunice $\mathrm{Oba}^{4}$; João Carlos Pinheiro Ferreira ${ }^{4 *}$
}

\begin{abstract}
Highlights:
An egg-yolk bovine media was evaluated for cryopreservation of buffalo semen.

The effect of adding sodium caseinate to this diluent was also studied.

The diluent was suitable for cryopreserving buffalo semen.

Freezing caused more damage to sperm cells than refrigeration.

Sodium caseinate did not lessen the harmful effects of cryopreservation.
\end{abstract}

\begin{abstract}
The use of cooled semen in artificial insemination operations results in higher pregnancy rates than the use of frozen semen. This result seems to be related to the more severe damage triggered by the freezing process than that observed during refrigeration. Due to its ability to bind to sperm-binding proteins and calcium ions, sodium caseinate has been studied as a substance capable of preventing early sperm capacitation, a significant cause of the decreased pregnancy rate resulting from the use of frozen semen. The first objective of this study was to evaluate whether a commercial egg yolk diluent developed for frozen bovine semen could be used for buffalo semen cryopreservation; the second objective was to investigate the effect of this diluent in combination with sodium caseinate during the procedures of buffalo sperm cryopreservation using flow cytometry and computer-assisted sperm analysis. In the first part of the study, comparing the results of spermatic kinetics and plasma and acrosomal membrane integrity, it was observed that the freezing process resulted in more cell damage than the cooling process. In the second part of the study, no effects of the addition of sodium caseinate to the egg yolk diluent were observed. From the results of the present study, it was possible to conclude that the egg yolk-based diluent was suitable for buffalo semen cryopreservation and that the addition of sodium caseinate did not decrease the harmful effects related to seminal cryopreservation.
\end{abstract}

Key words: BSP. Buffalo. Casein. Cryopreservation. Sperm.

\footnotetext{
${ }^{1}$ Discente do Curso de Mestrado do Programa de Pós-Graduação em Biotecnologia Animal, Faculdade de Medicina Veterinária e Zootecnia, FMVZ, Botucatu, SP, Brasil. E-mail: fernandoevaristo.mv@gmail.com

2 Discente do Curso de Doutorado do Programa de Pós-Graduação em Biotecnologia Animal, FMVZ, Botucatu, SP, Brasil. E-mail: jaque.veterinaria@live.com

3 Assistente Suporte Acadêmico IV, Departamento de Cirurgia Veterinária e Reprodução Animal, , FMVZ, Botucatu, SP, Brasil. E-mail: camila.freitas-dellaqua@unesp.br

4 Profs. Drs., Departamento de Cirurgia Veterinária e Reprodução Animal, FMVZ, Botucatu, SP, Brasil. E-mail: papa@fmvz. unesp.br; eunice.oba@unesp.br; joao.cp.ferreira@unesp.br

5 Prof. Dr., Departamento de Clínica e Cirurgia Veterinária, Universidade Federal de Minas Gerais, UFMG, Belo Horizonte, MG, Brasil. E-mail: henrym2601@gmail.com

* Author for correspondence
} 


\section{Resumo}

O uso de sêmen resfriado em operações de inseminação artificial resulta em taxas de prenhez mais altas do que o uso de sêmen congelado. Esse resultado parece estar relacionado aos danos mais severos desencadeados pelo processo de congelação, quando comparado com o de refrigeração. Devido à sua capacidade de se ligar às proteínas ligadoras de espermatozoides e íons cálcio, o caseinato de sódio foi estudado quanto a sua capacidade de prevenir a capacitação espermática precoce, uma causa significativa de diminuição da taxa de prenhez com o uso de sêmen congelado. O primeiro objetivo deste estudo foi avaliar se um diluidor comercial a base de gema de ovo, destinado à congelação de sêmen bovino, poderia ser usado para a criopreservação de sêmen bubalino; o segundo objetivo foi investigar o efeito da adição do caseinato de sódio ao diluidor estudado durante os procedimentos de criopreservação de espermatozoides bubalinos. Foram empregadas a citometria de fluxo e a análise computadorizada do movimento espermático como métodos de avaliação seminal. Na primeira fase do estudo, comparando-se os resultados da cinética espermática e da integridade das membranas plasmática e acrossomal, observou-se que o processo de congelação promoveu mais danos celulares que o processo de resfriamento. Na segunda fase do estudo, não foram observados efeitos benéficos da adição de caseinato de sódio ao diluente empregado. A partir dos resultados do presente estudo, foi possível concluir que o diluente à base de gema de ovo foi adequado para a criopreservação do sêmen de bubalino e que a adição do caseinato de sódio não diminuiu os efeitos deletérios desencadeados pelo processo de criopreservação seminal.

Palavras-chave: BSP. Búfalo. Caseína. Criopreservação. Espermatozoide.

\section{Introduction}

Artificial insemination is performed predominantly using frozen semen; however, freezing procedures involve a series of potentially deleterious processes to spermatozoa, such as the formation of free radicals and intracellular ice crystals, which decrease sperm viability after thawing (Watson, 2000; Souza \& Ferreira, 2007; Ugur et al., 2019).

A new alternative in fixed-time artificial insemination (FTAI) programs in cattle is the use of refrigerated semen with or without glycerol. In a study involving Nellore bulls, the conception rate was significantly higher with the use of 24-hour cooled semen diluted with Botu-Bov ${ }^{\circledR}$ with 7\% glycerol than with 24-hour cooled semen diluted with Botu-Bov ${ }^{\circledR}$ without glycerol or frozen with the same diluent with 7\% glycerol (51\%, 44\%, 41\%, respectively) (Papa et al., 2015).

The reason that frozen semen presents with lower fertility rates than cooled semen is related to the higher degree of damage and cellular alteration inflicted on sperm by the freezing process, particularly those related to plasma membrane lipid loss (Watson, 2000).

Casein is an essential component of milk and represents approximately $75-80 \%$ of its proteins (Fox \& McSweeney, 1998); this protein is an important molecule responsible for the cryoprotective properties of milk (Battelier et al., 1998, 2001). Similar to egg yolk, casein prevents the loss of lipids from the sperm membrane and decreases the binding of sperm-binding proteins (BSPs) to spermatozoa (Batellier, Magistrini, Fauquant, \& Palmer, 1997; Bergeron, Brindle, Blondin, \& Manjunath, 2007; Lusignan, Bergeron, Lafleur, \& Manjunath, 2011; Pagl, Aurich, Müller-Schlösser, Kankkofer, \& CAurich, 2006), a fundamental process in the adequate cryopreservation of bovine semen (Bergeron et al., 2007).

In a recent study conducted in our laboratory studying the effect of the addition of sodium caseinate to the commercial media Botu-Bov ${ }^{\circledR}$, higher postthawed sperm motility and a higher pregnancy rate after FTAI were obtained when the media contained $2 \%$ sodium caseinate (Diniz, 2017). 
Thus, based on the previous results obtained in bovines, the objective of this work was to evaluate whether egg yolk-based Botu-Bov supplemented with $7 \%$ glycerol, with or without the addition of $2 \%$ sodium caseinate, is suitable for the cryopreservation of buffalo semen.

\section{Material and Methods}

\section{Ethical aspects}

The project was carried out according to the ethical recommendation of the Brazilian College of Animal Experimentation (CONCEA) and approved by the FMVZ-Unesp's Ethics Committee on the Use of Animals (permit number 0166/2018).

\section{Animals}

Nine Murrah bulls (Bubalus bubalis) aged two to ten years old were used. After semen collection performed with an artificial vagina, total motility, vigor, and spermatic concentration were determined. Then, using wet sperm preparation techniques, morphological evaluation of spermatozoa was performed under phase-contrast microscopy (400 X - Leyca - DM 500, Wetzlaretzlar - Germany). Only ejaculates with at least $70 \%$ motility, vigor 3 (on a scale of 0-5), major defects below $10 \%$, and minor defects below 20\% (Colégio Brasileiro de Reprodução Animal [CBRA], 2013) were used.

\section{Experiment 1 ( $n=9$ ejaculates $)$}

Seminal samples diluted to $30 \times 10^{6}$ spermatozoa/ $\mathrm{mL}$ with commercial egg yolk media Botu-Bov ${ }^{\circledR}$ with 7\% glycerol (Botupharma, Botucatu/Brazil) were packed in $0.25 \mathrm{~mL}$ straws (IMV Technologies, L'Aigle Cedex, France) and kept in a polystyrene thermal box at $12^{\circ} \mathrm{C}$ for three hours while being transported from the farm to the faculty laboratory, where they were processed and evaluated according to the following groups: Control: assessed upon arrival at the laboratory; Refrigerated $24 \mathrm{H}$ : refrigerated for 24 hours at $5^{\circ} \mathrm{C}$; Refrigerated $48 \mathrm{H}$ : refrigerated for 48 hours at $5^{\circ} \mathrm{C}$; and Frozen. Before each evaluation, the samples were heated in a water bath at $37^{\circ} \mathrm{C}$ for $5 \mathrm{~min}$.

\section{Experiment 2 ( $n=12$ ejaculates)}

The seminal samples were divided into two aliquots and diluted to $30 \times 10^{6}$ spermatozoa $/ \mathrm{mL}$ with the same media as experiment 1 (Botu-Bov ${ }^{\circledR}$ with $7 \%$ glycerol) with or without $2 \%$ sodium caseinate. Then, the samples were packed in 0.25 $\mathrm{mL}$ straws (IMV Technologies, L'Aigle Cedex, France) and kept in a polystyrene thermal box at $12^{\circ} \mathrm{C}$ for three hours while being transported from the farm to the laboratory, where they were processed and evaluated according to the following groups: Control and Caseinate Control: assessed upon arrival at the laboratory; Refrigerated $24 \mathrm{H}$ and Refrigerated Caseinate $24 \mathrm{H}$ : refrigerated for 24 hours at $5^{\circ} \mathrm{C}$; Refrigerated $48 \mathrm{H}$ and Refrigerated Caseinate $48 \mathrm{H}$ : refrigerated for 48 hours at $5^{\circ} \mathrm{C}$; and Frozen and Frozen Caseinate. Before each evaluation, the straws were heated in water baths at $37^{\circ} \mathrm{C}$ for $5 \mathrm{~min}$.

\section{Cryopreservation protocols}

In both experiments, the seminal samples were cooled in a passive cooling box (Botu-Flex ${ }^{\circledR}$ : Botupharma Ltda., Botucatu, São Paulo, Brazil) at a rate of $0.5^{\circ} \mathrm{C} / \mathrm{min}$ down to $5^{\circ} \mathrm{C}$.

For freezing, the initial cooling of the samples was performed in an automatic cooler (MiniTub ${ }^{\circledR}$ : Minitub do Brasil Ltda., Porto Alegre, Rio Grande do Sul, Brazil) at a rate of $3^{\circ} \mathrm{C} / \mathrm{min}$ down to $5^{\circ} \mathrm{C}$, and the samples were maintained at this temperature for four hours. Subsequently, the straws were transferred to a $45-\mathrm{L}$ polystyrene isothermic box where they remained $3 \mathrm{~cm}$ above a $3.5 \mathrm{~cm}$ layer of a liquid nitrogen (NL) slide for $20 \mathrm{~min}$; after 
this period, the straws were immersed in the NL and then stored in a cryogenic container at $-196^{\circ} \mathrm{C}$ (Zorzetto, 2013).

\section{Semen analyses}

For the evaluation of sperm kinetics, total motility (MT, \%), progressive motility (MP, \%), and percentage of sperm with rapid movements (RAP, $\%$ ) were determined using computer-assisted sperm analysis (CASA, HTM-IVOS 12, Hamilton Thorne Research, Beverly, MA, USA).

Additionally, the samples from the frozen groups were submitted to a Slow Thermal Resistance Test (STRT), maintained at $37^{\circ} \mathrm{C}$ for two hours in a water bath, and then again evaluated for sperm kinetics.

\section{Flow cytometry}

After the evaluation of sperm kinetics, all samples, except those from the Control and Refrigerated groups in experiment 2, were analyzed by flow cytometry with a BD LSR Fortessa device (Becton Dickinson, Mountain View, CA, USA) equipped with the following excitation lasers: blue, $488 \mathrm{~nm}, 100 \mathrm{~mW}$, with emission filters $530 / 30 \mathrm{~nm}$ and 695/40 nm; red, $640 \mathrm{~nm}, 40 \mathrm{~mW}$ with emission filter $660 / 20 \mathrm{~nm}$; and violet, $405 \mathrm{~nm}, 100 \mathrm{~mW}$, with emission filter $450 / 50 \mathrm{~nm}$. In each test, at least 10,000 cells per sample were analyzed, and the results were analyzed by BD FACSDiva software ${ }^{\mathrm{TM}}$ v 6.1 .

Initially, the samples were diluted at a concentration of $5 \times 10^{6}$ spermatozoa $/ \mathrm{mL}$ in modified TALP-PVA medium (100 mM NaCl; $3.1 \mathrm{mM} \mathrm{KCl}$; $25.0 \mathrm{mM} \mathrm{NaHCO} ; 0.3 \mathrm{mM} \mathrm{NaH} \mathrm{PO}_{4} ; 21.6 \mathrm{mM}$ DL-sodium lactate $60 \% ; 2.0 \mathrm{mM} \mathrm{CaCl} 2 ; 0.4 \mathrm{mM}$ $\mathrm{MgCl}_{2} ; 10.0 \mathrm{mM}$ HEPES-free acid; $1.0 \mathrm{mM}$ sodium pyruvate; $1.0 \mathrm{mg} / \mathrm{mL}$ polyvinyl-PVA alcohol; and $25 \mu \mathrm{g} / \mathrm{mL}$ gentamicin) (Parrish, Susko-Parrish, Winer, \& First, 1988) plus $7 \mu \mathrm{M}$ Hoechst 33342 for elimination of debris and correct acquisition of only cellular events.
The association of propidium iodide (PI) and FITC-PSA (Pisum sativum agglutinin conjugated to fluorescein isothiocyanate) was used to evaluate the integrity of plasma and acrosome membranes according to Freitas-Dell'Aqua et al. (2012). For this, in a sample of $200 \mu \mathrm{L}$ of diluted semen, $1.5 \mu \mathrm{M}$ PI and 2 ng FITC-PSA were added, and the resulting mixture was incubated for 5 min under light.

In the evaluation of mitochondrial potential (PM) and superoxide $\left(\mathrm{O}_{2}^{-}\right)$production in the mitochondrial matrix, the association of Yopro (YP; cell marker of destabilized plasma membranes), MitoStatus Red (MST; mitochondrial potential) and MitoSOXTM Red (MSR; generation of $\mathrm{O}_{2}$-anions in the mitochondrial matrix) was assessed according to the protocol already described (Diniz, 2017). For this, in a sample of $500 \mu \mathrm{L}$ of diluted semen, $25 \mathrm{nM}$ YP, $20 \mu \mathrm{M}$ MST, and $2 \mu \mathrm{M}$ MSR were added, and this mixture was incubated at $37^{\circ} \mathrm{C}$ for $20 \mathrm{~min}$.

The association of CM-H2DCFDA (C6827, Life Technologies) with propidium iodide was used to evaluate the intracellular production of hydrogen peroxide $\left(\mathrm{H}_{2} \mathrm{O}_{2}\right.$. For this purpose, $1.5 \mu \mathrm{M}$ propidium iodide and $1 \mu \mathrm{M}$ CM-H2DCFDA were added to 500 $\mu \mathrm{L}$ of diluted semen and incubated for $20 \mathrm{~min}$ at $37^{\circ} \mathrm{C}$.

The probe C11-BODYPY (D-3861; Molecular Probes) was used for the evaluation of lipid peroxidation (PERO). For this, in a sample of $500 \mu \mathrm{L}$ of diluted semen, $0.5 \mu \mathrm{L}$ of C11BODIPY581/591 (1 $\mathrm{mg} / \mathrm{mL}), 5 \mu \mathrm{L}$ of IP $(50 \mu \mathrm{g} / \mathrm{mL})$, and $5 \mu \mathrm{L}$ of H342 $(100 \mu \mathrm{g} / \mathrm{mL})$ were added and incubated for $30 \mathrm{~min}$ at $37^{\circ} \mathrm{C}$. After incubation, two consecutive washes per centrifugation at $300 \mathrm{~g}$ for $5 \mathrm{~min}$ with TALP-PVA were performed, and the pellet was resuspended in $300 \mu \mathrm{L}$ of TALP-PVA (Guasti et al., 2012).

\section{Statistical analysis}

All analyses were performed using the SigmaPlot 11.0 program. When only two treatments were compared, data with normal distributions were 
evaluated by the t-test. For nonnormally distributed data, the Mann-Whitney nonparametric U test was employed. For the comparison of three or more treatments, ANOVA was used for data with normal distributions, and the Kruskal-Wallis test was used for nonnormally distributed data.

The results are presented as the means \pm standard errors of the mean (SEMs), with $\mathrm{P}<0.05$ considered significant.

\section{Results}

\section{Experiment 1}

The values of MT, MP, and RAP were not different between the Control and Refrigerated $24 \mathrm{H}$ groups; however, the frozen group presented lower values of these variables than the Control and Refrigerated $24 \mathrm{H}$ groups. The Refrigerated $48 \mathrm{H}$ group showed values similar to those of the Refrigerated $24 \mathrm{H}$ group; however, its MT and RAP values were similar to those of the frozen group (table 1).

\section{Table 1}

Mean values \pm EPM of the kinetics parameters of Murrah Buffalo (B. bubalis) semen cryopreserved with egg yolk-based media* $(n=9)$

\begin{tabular}{lcccc}
\hline & Control & Refrigerated 24 H & Refrigerated 48 H & Frozen-thawed \\
\cline { 2 - 5 } MT $(\%)$ & $85.0 \pm 1.7^{\mathrm{a}}$ & $83.0 \pm 3.0^{\mathrm{a}}$ & $74.0 \pm 5.0^{\mathrm{ab}}$ & $43.0 \pm 7.0^{\mathrm{b}}$ \\
MP (\%) & $71.0 \pm 1.9^{\mathrm{a}}$ & $66.0 \pm 3.3^{\mathrm{ab}}$ & $56.0 \pm 4.1^{\mathrm{b}}$ & $35.0 \pm 5.6^{\mathrm{c}}$ \\
RAP $(\%)$ & $84.0 \pm 1.8^{\mathrm{a}}$ & $81.0 \pm 2.6^{\mathrm{a}}$ & $72.0 \pm 5.3^{\mathrm{ab}}$ & $40.0 \pm 6.7^{\mathrm{b}}$ \\
\hline
\end{tabular}

* Botu-Bov ${ }^{\circledR}$ with 7\% glycerol (Botupharma, Botucatu/Brazil), MT: Total motility, MP: progressive motility, RAP: percentage of spermatozoa with rapid movement. Different letters in the same line indicate statistical difference $(\mathrm{P}<0.05)$.

The concentration of $\mathrm{O}_{2}^{-}$in the Control and Refrigerated $24 \mathrm{H}$ groups was lower than that in the frozen group. The PERO indexes were similar between the Control and Refrigerated $24 \mathrm{H}$ and $48 \mathrm{H}$ groups and between the Refrigerated $24 \mathrm{H}$ and $48 \mathrm{H}$ and Frozen groups; however, the Frozen group had higher PERO indexes than the Control group. The concentration of $\mathrm{H}_{2} \mathrm{O}_{2}$ was lower in the frozen group only when compared with that in the Refrigerated $48 \mathrm{H}$ group (table 2).

Table 2

Mean values \pm EPM of the oxidative stress parameters of Murrah buffalo (B. bubalis) semen cryopreserved with egg yolk-based media* $(n=9)$

\begin{tabular}{lcccc}
\hline & Control & Refrigerated $24 \mathrm{H}$ & Refrigerated 48 H & Frozen-thawed \\
\hline $\mathrm{O}_{2}^{-}(\%)$ & $21.8 \pm 2.1^{\mathrm{a}}$ & $28.3 \pm 3.2^{\mathrm{ab}}$ & $39.1 \pm 5.8^{\mathrm{bc}}$ & $70.1 \pm 6.5^{\mathrm{c}}$ \\
$\mathrm{O}_{2}^{-}(\mathrm{UA})$ & $106.0 \pm 22.0^{\mathrm{a}}$ & $181.0 \pm 49.0^{\mathrm{a}}$ & $356.0 \pm 123.0^{\mathrm{ab}}$ & $940.0 \pm 209.5^{\mathrm{b}}$ \\
$\mathrm{PERO}(\%)$ & $2.5 \pm 0.7^{\mathrm{a}}$ & $7.4 \pm 2.2^{\mathrm{ab}}$ & $5.9 \pm 1.6^{\mathrm{ab}}$ & $19.6 \pm 4.6^{\mathrm{b}}$ \\
$\mathrm{H}_{2} \mathrm{O}_{2}(\mathrm{UA})$ & $65.0 \pm 17.0^{\mathrm{ab}}$ & $60.0 \pm 8.9^{\mathrm{ab}}$ & $70.1 \pm 9.3^{\mathrm{a}}$ & $39.1 \pm 3.6^{\mathrm{b}}$ \\
\hline
\end{tabular}

* Botu-Bov ${ }^{\circledR}$ with 7\% glycerol (Botupharma, Botucatu/Brazil), $\mathrm{O}_{2}^{-}(\%)$ : Percentage of cells with a high concentration of superoxide anion, $\mathrm{O}_{2}^{-}$(UA): Level of superoxide anion in the total sample, PERO (\%): Percentage of cells with lipid peroxidation, $\mathrm{H}_{2} \mathrm{O}_{2}$ (UA): hydrogen peroxide concentration in whole cells. Different letters in the same line indicate statistical difference $(\mathrm{P}<0.05)$.

The percentage of cells with plasma and acrosome membrane integrity (MPAI) and the mitochondrial potential of cells without membrane destabilization (PM) were lower in the frozen group. The percentage of cells without membrane destabilization (CSDM) and with high mitochondrial potential (APM) was lower in the Refrigerated $48 \mathrm{H}$ and frozen groups (table 3). 
Table 3

Mean values \pm EPM of the sperm membranes destabilization and mitochondrial potential parameters of Murrah buffalo (B. bubalis) semen cryopreserved with egg yolk-based media* $(n=9)$

\begin{tabular}{lcccc}
\hline & Control & Refrigerated 24 H & Refrigerated 48 H & Frozen-thawed \\
\hline APM (\%) & $78.2 \pm 2.1^{\mathrm{a}}$ & $75.7 \pm 2.2^{\mathrm{a}}$ & $69.2 \pm 3.3^{\mathrm{b}}$ & $29.5 \pm 5.6^{\mathrm{c}}$ \\
MPAI (\%) & $80.4 \pm 2.3^{\mathrm{a}}$ & $78.9 \pm 2.2^{\mathrm{a}}$ & $72 \pm 3.2^{\mathrm{a}}$ & $34.3 \pm 6.3^{\mathrm{b}}$ \\
CSDM (\%) & $78.9 \pm 1.9^{\mathrm{a}}$ & $76.7 \pm 2.3^{\mathrm{a}}$ & $70.7 \pm 3.4^{\mathrm{b}}$ & $30.8 \pm 5.7^{\mathrm{b}}$ \\
PM (UA) & $12128.0 \pm 2025.0^{\mathrm{a}}$ & $9775.0 \pm 1905.0^{\mathrm{a}}$ & $6784.0 \pm 1701.0^{\mathrm{a}}$ & $1689.0 \pm 542.0^{\mathrm{b}}$ \\
\hline
\end{tabular}

* Botu-Bov ${ }^{\circledR}$ with 7\% glycerol (Botupharma, Botucatu/Brazil), APM: Percentage of cells with high mitochondrial potential; MPAI: Percentage of cells with intact plasma membrane and acrosome membrane; CSDM; Percentage of cells without membrane destabilization; PM: Qualitative evaluation of the mitochondrial potential of cells without membrane destabilization. Different letters on the same line indicate statistical difference $(\mathrm{P}<0.05)$.

\section{Experiment 2}

There was no effect of treatment on MT, MP, or RAP (table 4). The differences appeared only when pre- and post- STRT values were compared within the frozen groups (frozen and frozen caseinate groups) (Table 5).

Table 4

Mean values \pm EPM of the sperm kinetics parameters of Murrah Buffalo (B. bubalis) semen cryopreserved with egg yolk-based media* with (CA) or without (BB) $2 \%$ sodium caseinate $(n=12)$.

\begin{tabular}{lcccccc}
\hline & \multicolumn{2}{c}{ Control } & \multicolumn{2}{c}{ Refrigerated 24 H } & \multicolumn{2}{c}{ Refrigerated 48 H } \\
\cline { 2 - 7 } & $\mathrm{Ca}$ & $\mathrm{Bb}$ & $\mathrm{Ca}$ & $\mathrm{Bb}$ & $\mathrm{Ca}$ & $\mathrm{Bb}$ \\
\cline { 2 - 7 } MT (\%) & $89.2 \pm 8.1$ & $89.3 \pm 8.1$ & $87.0 \pm 4.1$ & $86.0 \pm 5.1$ & $70.9 \pm 9.9$ & $84.0 \pm 5.3$ \\
MP (\%) & $40.6 \pm 4.1$ & $45.2 \pm 5.2$ & $49.0 \pm 4.6$ & $52.0 \pm 5.5$ & $36.8 \pm 7.2$ & $45.0 \pm 5.8$ \\
RAP (\%) & $63.0 \pm 6.9$ & $69.1 \pm 7.2$ & $60.0 \pm 8.0$ & $64.0 \pm 8.2$ & $46.0 \pm 10.0$ & $54.0 \pm 8.0$ \\
\hline
\end{tabular}

* Botu-Bov ${ }^{\circledR}$ with 7\% glycerol (Botupharma, Botucatu/Brazil), MT: Total motility, MP: progressive motility, RAP: percentage of spermatozoa with rapid movement. CONTROL: diluted semen with diluent for freezing, $24 \mathrm{H}$ : 24 hours of refrigeration, $48 \mathrm{H}$ : 48 hours of refrigeration.

\section{Table 5}

Mean values \pm EPM of sperm kinetics parameters of Murrah Buffalo (B. bubalis) semen frozen with egg yolkbased media* with (CA) or without $(B B) 2 \%$ sodium caseinate $(n=12)$

\begin{tabular}{ccccccc}
\hline & \multicolumn{2}{c}{ MT (\%) } & \multicolumn{2}{c}{ MP $(\%)$} & \multicolumn{2}{c}{ RAP $(\%)$} \\
\cline { 2 - 7 } & Frozen-thawed & STRT & Frozen-thawed & STRT & Frozen-thawed & STRT \\
\cline { 2 - 7 } $\mathrm{Ca}$ & $45.7 \pm 6.5^{\mathrm{aA}}$ & $11.0 \pm 5.2^{\mathrm{aB}}$ & $37.5 \pm 5.5^{\mathrm{aA}}$ & $7.0 \pm 3.8^{\mathrm{aB}}$ & $42.5 \pm 6.3^{\mathrm{aA}}$ & $9.0 \pm 5^{\mathrm{aB}}$ \\
$\mathrm{Bb}$ & $42.9 \pm 7.0^{\mathrm{aA}}$ & $8.0 \pm 4.8^{\mathrm{aB}}$ & $36.6 \pm 5.8^{\mathrm{aA}}$ & $6.0 \pm 4^{\mathrm{aB}}$ & $41.4 \pm 6.9^{\mathrm{aA}}$ & $6.8 \pm 4^{\mathrm{aB}}$ \\
\hline
\end{tabular}

* Botu-Bov ${ }^{\circledR}$ with 7\% glycerol (Botupharma, Botucatu/Brazil), MT: total motility, MP progressive motility, RAP: percentage of sperm with rapid movement. STRT: Frozen-thawed evaluated after slow thermal resistance test $\left(2 \mathrm{~h}\right.$ at $\left.37^{\circ} \mathrm{C}\right)$. Different lowercase letters in the same column indicate statistical difference; different uppercase letters in the same row indicate statistical difference $(\mathrm{P}<0.05)$. 
When the frozen and frozen caseinate groups were compared in terms of the morphofunctional variables related to oxidative stress, there was no difference between them, except for the percentage of cells with a high concentration of $\mathrm{O}_{2}^{-}$after the STRT test, which was higher in the frozen group (table 6).

Table 6

Mean values \pm EPM of oxidative stress parameters of Murrah buffalo (B. bubalis) semen frozen with egg yolk based media* with $(C A)$ or without $(B B) 2 \%$ sodium caseinate $(n=12)$

\begin{tabular}{lcccc}
\hline & \multicolumn{2}{c}{ Frozen-thawed } & \multicolumn{2}{c}{ STRT } \\
\cline { 2 - 5 } $\mathrm{O}_{2}^{-}(\%)$ & $\mathrm{CA}$ & $\mathrm{BB}$ & $\mathrm{CA}$ & BB \\
\cline { 2 - 5 } $\mathrm{O}_{2}^{-}(\mathrm{UA})$ & $77.7 \pm 4.8^{\mathrm{a}}$ & $70.1 \pm 6.1^{\mathrm{a}}$ & $79.8 \pm 4.0^{\mathrm{a}}$ & $75.7 \pm 5.1^{\mathrm{a}}$ \\
$\mathrm{H}_{2} \mathrm{O}_{2}$ (UA) & $651.5 \pm 54.7^{\mathrm{a}}$ & $801.7 \pm 97.3^{\mathrm{a}}$ & $649.5 \pm 47.5^{\mathrm{a}}$ & $920.1 \pm 85.8^{\mathrm{b}}$ \\
$\left.\mathrm{PERO}^{\mathrm{a}} \%\right)$ & $333.3 \pm 167.7^{\mathrm{a}}$ & $342.0 \pm 254.7^{\mathrm{a}}$ & $89.4 \pm 8.3^{\mathrm{a}}$ & $86.7 \pm 13.6^{\mathrm{a}}$ \\
\hline
\end{tabular}

* Botu-Bov ${ }^{\circledR}$ with 7\% glycerol (Botupharma, Botucatu/Brazil), STRT: Frozen-thawed evaluated after slow thermal resistance test $\left(2 \mathrm{~h}\right.$ at $\left.37^{\circ} \mathrm{C}\right), \mathrm{O}_{2}^{-}(\%)$ : Percentage of cells with a high concentration of superoxide anion, $\mathrm{O}_{2}^{-}(\mathrm{UA})$ : concentration of superoxide anion in the total sample, PERO (\%): Percentage of cells with lipid peroxidation, $\mathrm{H}_{2} \mathrm{O}_{2}$ (UA): hydrogen peroxide concentration in total cells. Different letters in the same line indicate statistical difference $(\mathrm{P}<0.05)$.

Similarly, no differences were observed membranes, except for the PM, which was lower in between the frozen and frozen caseinate groups the frozen caseinate group after STRT (table 7).

for the variables related to the evaluation of sperm

Table 7

Mean values \pm EPM of the sperm membranes destabilization and mitochondrial potential parameters of Murrah buffalo (B. bubalis) semen frozen with egg yolk-based media* with (CA) or without (BB) $2 \%$ sodium caseinate $(n=12)$

\begin{tabular}{lcccc}
\hline & \multicolumn{2}{c}{ Frozen-thawed } & \multicolumn{2}{c}{ STRT } \\
\cline { 2 - 5 } APM (\%) & \multicolumn{1}{c}{ CA } & BB & CA & BB \\
\cline { 2 - 5 } MPAI (\%) & $19.9 \pm 5.1^{\mathrm{a}}$ & $28.5 \pm 5.9^{\mathrm{a}}$ & $17.3 \pm 3.4^{\mathrm{a}}$ & $23.1 \pm 5.2^{\mathrm{a}}$ \\
CSDM (\%) & $24.0 \pm 5.6^{\mathrm{a}}$ & $33.9 \pm 6.7^{\mathrm{a}}$ & $20.1 \pm 3.6^{\mathrm{a}}$ & $26 \pm 5.7^{\mathrm{a}}$ \\
PM (UA) & $91.4 \pm 2.86^{\mathrm{a}}$ & $87.8 \pm 3.5^{\mathrm{a}}$ & $91.0 \pm 3.3^{\mathrm{a}}$ & $88.1 \pm 3.7^{\mathrm{a}}$ \\
\hline
\end{tabular}

* Botu-Bov ${ }^{\circledR}$ with 7\% glycerol (Botupharma, Botucatu/Brazil), STRT: Frozen-thawed evaluated after slow thermal resistance test $\left(2 \mathrm{~h}\right.$ at $\left.37^{\circ} \mathrm{C}\right), \mathrm{APM}(\%)$ : Percentage of cells with high mitochondrial potential, MPAI (\%): Percentage of cells with intact plasma membrane and acrosome, CSDM (\%): Percentage of cells without membrane destabilization. PM (AU): Qualitative evaluation of the mitochondrial potential of cells without membrane destabilization. Different letters in the same line indicate statistical difference $(\mathrm{P}<0.05)$. 


\section{Discussion}

The results of experiment 1 indicate that cooling buffalo semen is a promising possibility for use in FTAI programs, mainly if considered the results obtained in the first 24 hours of refrigeration. In cattle, the use and superiority of refrigerated semen, compared to post-thawed semen, in FTAI programs was reported for the first time in a study conducted in our department (Papa et al., 2015). Since then, its use has been progressively increasing (BorgesSilva et al., 2016; Tarragó, 2017; J. C. B. Silva et al., 2019). Similarly, the commercial media tested, Botu-Bov $^{\circledR}$, supplemented with 7\% glycerol, although developed for cattle, proved to be suitable for buffaloes.

The results obtained after 24 hours of refrigeration were systematically higher than those obtained after thawing, except for the percentage of PERO and concentration of $\mathrm{H}_{2} \mathrm{O}_{2}$, which were similar between these two groups. Although a drop in the sperm quality index after 48 hours of refrigeration has previously been verified, the results observed in the Control group were quite similar to those noted for the Refrigerated $24 \mathrm{H}$ group. When these results are analyzed from a biological point of view, they indicate the possibility of using semen refrigerated for 48 hours in FTAI programs. It should be noted that for some variables (MT, $\mathrm{H}_{2} \mathrm{O}_{2}$, APM, MPAI, $\mathrm{PM}$ ), the results observed for Refrigerated groups were better than those found for the frozen group.

As well characterized in cattle, the reduced post-thawed fertility is due to the severity of cell damage that occurs during the freezing process (Watson, 2000). The evaluations carried out in our study also demonstrated that the freezing process was more harmful to buffalo spermatozoa than refrigeration. These results partially explain why Almeida (2018), employing the same media as our study, obtained a higher pregnancy rate in a buffalo FTAI program with 24-hour refrigerated semen than with post-thawed samples regardless of whether the inseminations were performed during favorable or unfavorable reproductive seasons $(57.8 \%$ versus $31.1 \%$ and $48.2 \%$ versus $34.6 \%$, respectively).

Cryocapacitation consists of a series of changes that occur in the plasma membrane of spermatozoa during the freezing process, which are quite similar to those observed during physiological capacitation (Bailey, Blodeau, \& Cormier, 2000). Cryocapacitation is an important phenomenon that explains why the freezing process decreases sperm motility and the fertility of post-thawed semen (Watson, 1995).

Several indicators can be used to infer the occurrence of cryocapacitation, including the generation of reactive oxygen species and plasma membrane changes (Bailey et al., 2000). In experiment 1, cryocapacitation-signaling alterations, such as a higher percentage of cells with a high concentration of $\mathrm{O}^{-}$and $\mathrm{PERO}$, a higher level of $\mathrm{O}^{-}$and $\mathrm{H}_{2} \mathrm{O}_{2}$, and a lower rate of cells without membrane destabilization, were evident in the frozen group.

Buffalo ejaculates with higher levels of BSPs have worse post-thawed quality (Singh et al., 2014); as BSPs are involved in the lipid changes of the capacitation process, the higher amount of these proteins can result in excessive removal of lipids from the plasma spermatozoa membrane (Manjunath, 2012). As sodium caseinate can bind to BSPs, preventing excessive membrane lipid loss, and sequester $\mathrm{Ca}^{+2}$, it has been indicated as a potential molecule for preventing early capacitation (Batellier et al., 1997; Bergeron et al., 2007; Silva, Seidel, Squires, Graham, \& Carnevale, 2012).

Unlike the observations by Diniz (2017) in cattle, in buffaloes, it was not possible to identify additional advantageous effects of the addition of sodium caseinate to the semen media studied. As the results of the post-thawed sperm variables were quite similar among the frozen and frozen caseinate groups, it was not possible to infer the protective effect of this molecule in preventing cryocapacitation in buffaloes. Even after STRT, these groups did not differ from each other. 
Finally, at the concentrations used in this study, it is also worth mentioning that no harmful effect was detected regarding the addition of sodium caseinate to the commercial media used in our research. As casein is the main milk protein (Fox \& McSweeney, 1998) and is responsible for its cryoprotective properties (Battelier et al., 1998, 2001), our results suggest that it is a potential substitute for milk in semen media. This possibility is of great importance for the development of new, chemically defined, and biologically safe media, an important goal in the seminal cryopreservation area (Olson \& Seidel, 2000; Emamverdi et al., 2015).

\section{Conclusion}

Botu-Bov media ${ }^{\circledR}$, with $7 \%$ glycerol, was successfully used in the cryopreservation of buffalo semen. However, the better-quality indicators observed for samples refrigerated for 24 hours compared with those found for the frozen samples indicate that refrigeration is an excellent alternative for FTAI programs.

The addition of sodium caseinate to the BotuBov media ${ }^{\circledR}$ did not prevent the appearance of cryocapacitation in the post-thawed samples, and no additional cryoprotective effect of its use was detected in this study. However, the addition of sodium caseinate also did not result in harmful effects on sperm quality, suggesting that this molecule may be an excellent candidate for the composition of chemically defined seminal media.

\section{References}

Almeida, J. (2018). Sêmen refrigerado e seu potencial de uso na inseminação artificial de búfalas (Bubalus bubalis), Tese de doutorado, Escola de Veterinária - Universidade Federal de Minas Gerais, Belo Horizonte, MG, Brasil.

Bailey, J. L., Blodeau, J. F., \& Cormier, N. (2000). Semen cryopreservation in domestic animals: A damaging and capacitating phenomenon minireview. Journal of Andrology, 21(1), 1-7. doi: 10.1002/j. 19394640.2000.tb03268.x
Batellier, F., Magistrini, M., Fauquant, J., \& Palmer, E. (1997). Effect of milk fractions on survival of equine spermatozoa. Theriogenology, 48(3), 391-410. doi: 10.1016/s0093-691x(97)00250-1

Battelier, F., Duchamp, G., Vidament, M., Arnaud, G., Palmer, E., \& Magistrini, M. (1998). Delayed insemination is successful with a new extender for storing fresh semen at $15{ }^{\circ} \mathrm{C}$ under aerobic conditions. Theriogenology, 50(2), 229-236. doi: 10.1016/s0093-691x(98)00130-7

Battelier, F., Vidament, M., Fauquant, J., Duchamp, G., Arnaud, G., Yvon, J. M., \& Magistrini, M. (2001). Advances in cooled semen technology. Animal Reproduction Science, 68(3-4), 181-190. doi: 10.1016/ S0378-4320(01)00155-5

Bergeron, A., Brindle, Y., Blondin, P., \& Manjunath, P. (2007). Milk caseins decrease the binding of the major bovine seminal plasma proteins to sperm and prevent lipid loss from the sperm membrane during sperm storage. Biology of Reproduction, 77(1), 120126. doi: 10.1095/biolreprod.106.058248

Borges-Silva, J. C., Silva, M. R., Marinho, D. B., Nogueira, E., Sampaio, D. C., Oliveira, L. O. F.,... Sartori, R. (2016). Cooled semen for fixed-time artificial insemination in beef cattle. Reproduction, Fertility and Development, 28(7), 1004-1008. doi: 10.1071/RD14185

Colégio Brasileiro de Reprodução Animal. (2013). Manual para exame andrológico e avaliação de semen animal (3a ed.). Belo Horizonte: CBRA.

Diniz, J. V. A. (2017). Utilização do caseinato de sódio na congelação de sêmen bovino, Tese de doutorado, Faculdade de Medicina Veterinária e Zootecnia, Botucatu, SP, Brasil.

Emamverdi, M., Zhandi, M., Shahneh, A. Z., Sharafi, M., Akhlaghi, A., Motlagh, M. K.,.. Davachi, N. D. (2015). Flow cytometric and microscopic evaluation of post-thawed ram semen cryopreserved in chemically defined home-made or commercial extenders. Animal Production Science, 55(4), 551558. doi: 10.1071/AN13215

Fox, P. F., \& McSweeney, P. L. H. (1998). Milk proteins. In Dairy Chemistry and Biochemistry, (pp. 230239). New York, NY: Kluwer Academic/Plenum Publishers.

Freitas-Dell'Aqua, C. P., Guasti, P. N., Monteiro, G. A., Maziero, R. R. D., Dell'Aqua, J. A., \& Papa, F. O. (2012). Flow cytometric analysis of fertile and subfertile frozen stallion spermatozoa. Animal Reproduction, 9(4), 941. 
Guasti, P. N., Freitas-Dell'Aqua, C. P., Maziero, R. R. D., Hartwig, F. P., Monteiro, G. A., Lisboa, F. P., \& Papa, F. O. (2012). Validation of flow cytometry for assessment of membrane lipid peroxidation of equine spermatozoa. Animal Reproduction, 9(4), 929.

Lusignan, M. F., Bergeron, A., Lafleur, M., \& Manjunath, P. (2011). The major proteins of bovine seminal plasma interact with caseins and whey proteins of milk extender. Biology of Reproduction, 85(3), 457464. doi: 10.1095/biolreprod.110.089961

Manjunath, P. (2012). New insights into the understanding of the mechanism of sperm protection by extender components. Animal Reproduction, 9(4), 809-815.

Olson, S. E., \& Seidel, G. E., Jr. (2000). Reduced oxygen tension and EDTA improve bovine zygote development in a chemically defined medium. Journal of Animal Science, 78(1), 152-157. doi: $10.2527 / 2000.781152 x$

Pagl, R., Aurich, J. E., Müller-Schlösser, F., Kankkofer, M., \& Aurich, C. (2006). Comparison of an extender containing defined milk protein fractions with a skim milk-based extender for storage of equine semen at $5{ }^{\circ} \mathrm{C}$. Theriogenology, 66(5), 1115-1122. doi: 10.1016/j.theriogenology.2006.03.006

Papa, P. M., Maziero, R. D., Guasti, P. N., Junqueira, C. R., Freitas-Dell'Aqua, C. P., Papa, F. O.,... Dell'Aqua Jr, J. A. (2015). Effect of glycerol on the viability and fertility of cooled bovine semen. Theriogenology, 83(1), 107-113. doi: 10.1016/j. theriogenology.2014.08.009

Parrish, J. J., Susko-Parrish, J., Winer, M. A., \& First, N. L. (1988). Capacitation of bovine sperm by heparin. Biology of Reproduction, 38(5), 1171-1180. doi: 10.1095/biolreprod38.5.1171

Silva, J. C. B., Silva, M. R., Silva, R. G. da, Nogueira, E., Oliveira, L. O. F. de, Abreu1, U. G. P. de,... Rodrigues, W. B. (2019). Use of bovine chilled semen: breaking paradigms. Brazilian Journal of Animal Reproduction, 43(2), 284-288.
Silva, M. A. C. da, Seidel, G. E., Squires, E. L., Graham, J. K., \& Carnevale, E. M. (2012). Effects of components of semen extenders on the binding of stallion spermatozoa to bovine or equine zonae pellucidae. Reproduction, 143(5), 577-585. doi: 10.1530/REP-11-0099

Singh, M., Ghosh, S. K., Prasad, J. K., Kumar, A., Tripathi, R. P., Bhure, S. K., \& Srivastava, N. (2014). Seminal PDC-109 protein vis-à-vis cholesterol content and freezability of buffalo Spermatozoa. Animal Reproduction Science, 144(1-2), 22-29. doi: 10.1016/j.anireprosci.2013.10.016

Souza, J. D. S., \& Ferreira, W. M. (2007). The role of vitamin $\mathrm{E}$ in animal nutrition and reproduction means of defense against free radicals. Nutritime Electronic Journal, 4(3), 456-461.

Tarragó, O. F. B. (2017). Sêmen refrigerado bovino reduz os danos espermáticos e aumenta a taxa de prenhez na IATF?. Tese de doutorado, Universidade de São Paulo, São Paulo, SP, Brasil.

Ugur, M. R., Abdelrahman, A. S., Evans, H. C., Gilmore, A. A., Hitit, M., Arifiantini, R. I., Purwantara, B., Kaya, A., \& Memili, E. (2019). Advances in cryopreservation of bull sperm. Frontiers in Veterinary Science, 6, 268. doi: 10.3389/ fvets. 2019.00268

Watson, P. F. (1995). Recent developments and concepts in the cryopreservation of spermatozoa and the assessment of their post-thawing function. Reproduction, Fertility and Development, 7(4), 871891. doi: 10.1071/RD9950871

Watson, P. F. (2000). The causes of reduced fertility with cryopreserved semen. Animal Reproduction Science, 60-61, 481-492. doi: 10.1016/S03784320(00)00099-3

Zorzetto, M. F. (2013). Avaliação do sêmen de búfalos em três meios de criopreservação. Dissertação de mestrado, Faculdade de Medicina Veterinária e Zootecnia, Botucatu, SP, Brasil. 